\title{
BLOOMING FLOWERS
}



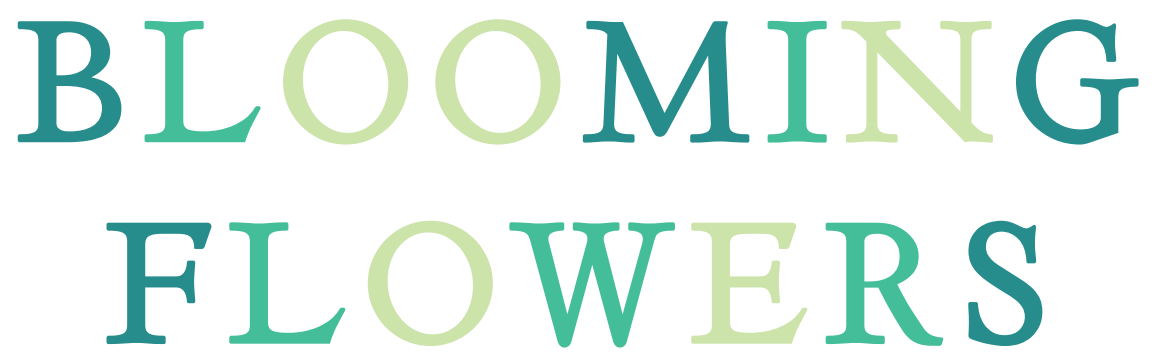

\section{A SEASONAL HISTORY OF \\ PLANTS AND PEOPLE}

\section{KASIA BODDY}

YALE UNIVERSITY PRESS NEW HAVEN AND LONDON 


\section{Copyright (C) 2020 Kasia Boddy}

All rights reserved. This book may not be reproduced in whole or in part, in any form (beyond that copying permitted by Sections 107 and 108 of the U.S. Copyright Law and except by reviewers for the public press) without written permission from the publishers.

For information about this and other Yale University Press publications, please contact:

U.S. Office: sales.press@yale.edu yalebooks.com

Europe Office: sales@yaleup.co.uk yalebooks.co.uk

Set in Adobe Garamond Pro by IDSUK (DataConnection) Ltd

Printed in Great Britain by Gomer Press Ltd, Llandysul, Ceredigion, Wales

Library of Congress Control Number: 2020932727

ISBN 978-0-300-24333-8

A catalogue record for this book is available from the British Library.

10987654321 
For Adele Wirszubska Boddy

and remembering Francis Andrew Boddy 
- vi - 
This is a world where there are flowers.

Henry David Thoreau 
- viii - 